\title{
Cytokine stimulation during Salmonella typhimurium sepsis in Itys mice
}

\author{
R. JOTWANI, Y. TANAKA, K. WATANABE*, K. TANAKA, N. KATO and K. UENO $\dagger$ \\ Institute of Anaerobic Bacteriology, Gifu University School of Medicine, Gifu 500 and + Gifu College of Medical \\ Technology, 795-1 Nagamine, Seki-shi Gifu 501-32, Japan
}

\begin{abstract}
Summary. Cytokine production was measured in mice during Salmonella typhimurium sepsis and intoxication. In mice given live $S$. typhimurium $(10 \mathrm{cfu} /$ mouse), by intra-peritoneal injection, serum levels of tumour necrosis factor (TNF)- $\alpha$ and interleukin- 6 increased steadily from day 1 until day 4 . Interferon- $\gamma$ levels showed a transient peak on day 3. Interleukin-1$\alpha$ levels were very low. There were high bacterial counts in the livers at day 3 and deaths occurred from day 4 onwards. Intraperitoneal injection of lipopolysaccharide or heat-killed bacteria also induced all of the cytokines, but their time of appearance and levels varied greatly. Cytokine induction by heat-killed bacteria was more marked. Endotoxaemia decreased with time during intoxication and increased during sepsis. Bioactive TNF, as measured by a cytotoxicity assay, was found only in mice given heat-killed bacteria.
\end{abstract}

\section{Introduction}

Salmonella typhimurium is a facultative intracellular parasite. Its proliferation in inbred strains of mice is genetically regulated by Ity genes. ${ }^{1}$ In Ity $^{\mathrm{r}}$ mice, resistance to $S$. typhimurium is controlled by modulation of interferon- $\gamma$ (IFN- $\gamma$ ), whereas in Ity ${ }^{\mathrm{s}}$ mice there is a logarithmic increase of S. typhimurium in the reticulo-endothelial system resulting in a fatal infection. In these latter animals, there is only a transient increase of IFN- $\gamma$ between the second and third day of infection. ${ }^{2}$ There are conflicting reports regarding the role of tumour necrosis factor- $\alpha$ (TNF- $\alpha$ ) during $S$. typhimurium infection. Elevation of TNF- $\alpha$ levels was not observed during $S$. typhimurium septicaemia in calves or in different mouse strains. ${ }^{3,4}$ The production and role of other inflammatory cytokines such as interleukin 1- $\alpha$ (IL-1 $\alpha)$ and interleukin 6 (IL-6) during $S$. typhimurium infection has not been well studied. The present study was conducted to analyse production of cytokines TNF- $\alpha$, IFN- $\gamma$, IL- $1 \alpha$ and IL- 6 during $S$. typhimurium infection of Ity ${ }^{\mathrm{s}}$ mice of strain C57BL/6J to provide an insight into the sequence of events that leads to sepsis in vivo. Cytokine profiles after administration of lipopolysaccharide (LPS) and heat-killed bacteria were also studied to investigate the difference in cytokine response between clinical sepsis and intoxication.

\section{Materials and methods}

Mice

Male C57BL/6J jcl (Japan CLEA) mice, 6-8 weeks old were used. A total of 63 mice was used in each group.

\section{Bacteria and inoculum preparation}

S. typhimurium ATCC 14028 was obtained from the American Type Culture Collection (Rockville, MD, USA). For inoculum preparation, a few colonies of $S$. typhimurium from an overnight culture on nutrient agar were suspended in pyrogen-free physiological saline and adjusted to a concentration of $100 \mathrm{cfu} / \mathrm{ml}$, as described by Matsuura and Galanos. ${ }^{5}$ Each mouse was given $0 \cdot 1 \mathrm{ml}$ of this suspension by intraperitoneal injection. The heat-killed bacterial suspensions were prepared as described by Freudenberg et al. ${ }^{2}$ For cytokine studies during intoxication, $0.1 \mathrm{ml}$ of pyrogen-free physiological saline, containing either $50 \mu \mathrm{g}$ dry weight of heat-killed bacteria (equivalent to $2.3 \times 10^{8} \mathrm{cfu}$ ) or $1.2 \mu \mathrm{g}$ of $S$. typhimurium LPS (Difco) was injected intraperitoneally into each mouse.

\section{Blood sampling and cytokine measurement}

Blood was collected by cardiac puncture from groups of seven mice at intervals of $1 \mathrm{~h}, 3 \mathrm{~h}, 6 \mathrm{~h}, 9 \mathrm{~h}$, $12 \mathrm{~h}, 1$ day, 2 days, 3 days and 4 days post-inoculation. In each group of seven mice, two test samples were prepared by pooling four sera into one and three into 
the other. TNF- $\alpha$, IFN- $\gamma$ and IL- $1 \alpha$ in serum were detected with Genzyme ELISA kits (Genzyme, Cambridge, MA, USA). IL-6 levels were determined with an Endogen ELISA kit (Endogen, Boston, MA, USA). All tests were performed in duplicate. For confirmation of the specificity of immunoreactive TNF- $\alpha$ measurement, $50 \mu$ l of mouse serum was neutralised with $1 \mu \mathrm{l}$ of anti-TNF monoclonal antibody (MAb) (Genzyme) at $37^{\circ} \mathrm{C}$ for $2 \mathrm{~h}$ before ELISA. Bioactivity of TNF- $\alpha$ was determined by an L-929 cell culture assay as described by Fisch and Gifford. ${ }^{6}$ One cytotoxic unit was defined as the amount that induced $50 \%$ cytotoxicity. Recombinant TNF- $\alpha$ (Genzyme) was used as a positive control in both neutralisation test and bioassay.

\section{Bacterial counts and endotoxin assay}

On day 3 post-infection, the livers of three mice infected with $S$. typhimurium were removed aseptically and homogenised, and samples were plated for bacterial counts. Endotoxin activity in the serum samples and in the pyrogen-free physiological saline used for injection was checked by the Limulus amoebocyte lysate assay kit (Endospecy test, Seikagaku Kagyo Co. Ltd, Tokyo, Japan). The kit was designed to measure endotoxin levels as low as 0.15 endotoxin units $(\mathrm{EU}) / \mathrm{ml}$.

\section{Results}

\section{Cytokine analysis}

Production of cytokines during infection with live $S$. typhimurium was detected from day 1 post-infection.
TNF- $\alpha$ and IL-6 levels increased from day 1 until day 4 , the last sampling time (fig. 1). IFN- $\gamma$ showed little increase until day 2 with a peak on the third day and a sharp decline by day 4 . IL-1 $\alpha$ levels remained very low throughout the experiment. Incubation of serum samples from all the time points with anti-TNF MAb completely neutralised TNF- $\alpha$ as detected by ELISA. None of the serum samples from any time point demonstrated TNF bioactivity as measured by the L929 cell culture assay.

Intraperitoneal injections of $S$. typhimurium LPS ( $1.2 \mu \mathrm{g} /$ mouse) or heat-killed bacteria $(50 \mu \mathrm{g} /$ mouse $)$ produced a more rapid induction of all the cytokines (TNF- $\alpha$, IFN- $\gamma$, IL- 6 and IL- $1 \alpha$ ) - within $6 \mathrm{~h}-$ in the serum as compared to infection with live bacteria (fig. $2 a, b, c, d)$. Stimulation of all the cytokines was more marked with heat-killed bacteria. Bioactive TNF was detected in the sera of mice given the heat-killed preparation and followed a similar pattern to the ELISA-reactive TNF, with a peak at $1 \mathrm{~h}$ (fig. 3).

\section{Liver counts and endotoxaemia}

Livers removed on day 3 from the mice infected with live $S$. typhimurium (10 cfu/mouse) contained large numbers of bacteria $\left(6.57 \times 10^{7} \mathrm{cfu} / \mathrm{g}\right.$ of liver). Consequently, mortality was evident from day 4 onwards and was $100 \%$ by day 6 . In the infected group, endotoxin levels increased steadily from day 1 until the fourth day (fig. 4). On the other hand, in the group given heat-killed bacteria, very high levels were observed until day 3 but had declined sharply by day 4 . No mortality was observed in the groups of mice given either heat-killed bacteria or LPS.

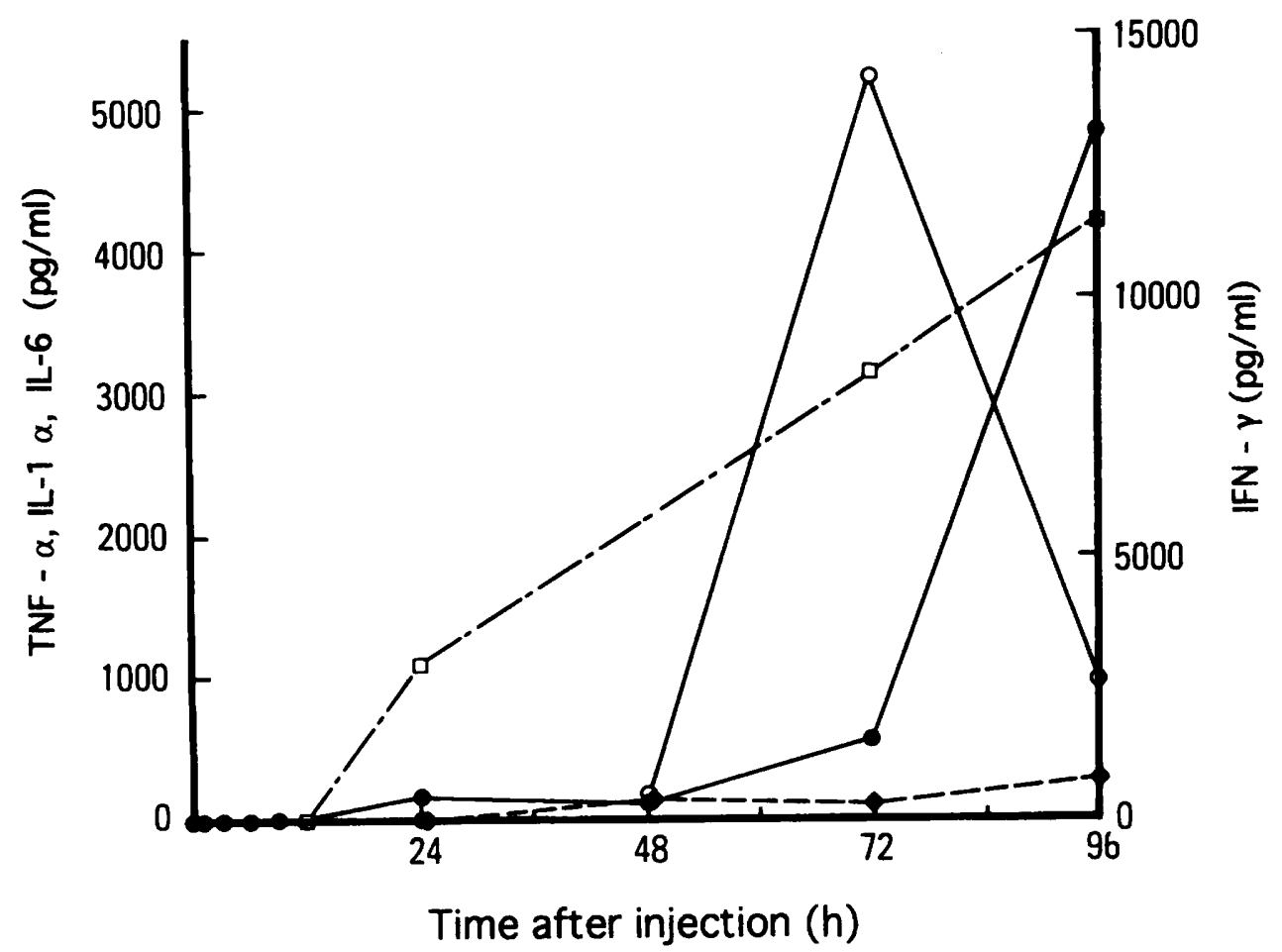

Fig. 1. TNF- $\alpha(--)$, IL-6 (- ---$)$, IFN- $\gamma\left(-O_{-}\right)$and IL- $1 \alpha(----)$ in sera from mice infected with 10 cfu of S. typhimurium. Each point represents the mean of four readings from two groups of mice. Serum samples were assayed by ELISA. 

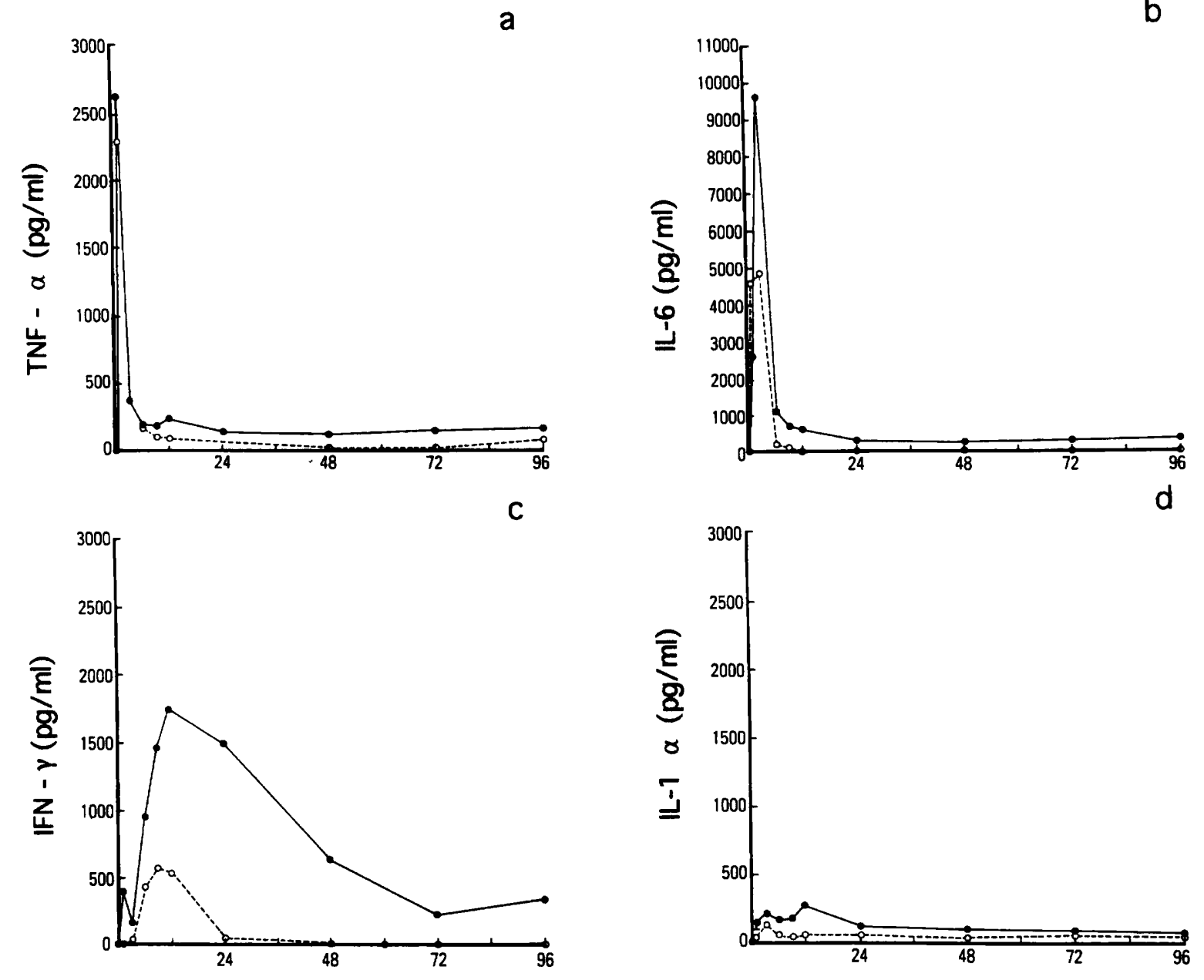

Time after injection $(h)$

Fig. 2. Cytokine levels in sera of mice after injection of S. typhimurium LPS $(1.2 \mu \mathrm{g} /$ mouse $)\left(--\mathrm{O}^{--}\right)$or heat-killed S. typhimurium (50 $\mu \mathrm{g}$ dry $\mathrm{wt} /$ mouse) (- - ) a, TNF- $\alpha$; b, IL-6; c, IFN- $\gamma ;$ d, IL-1 $\alpha$. Each point represents the mean of four readings from two groups of mice. Samples were assayed by ELISA.

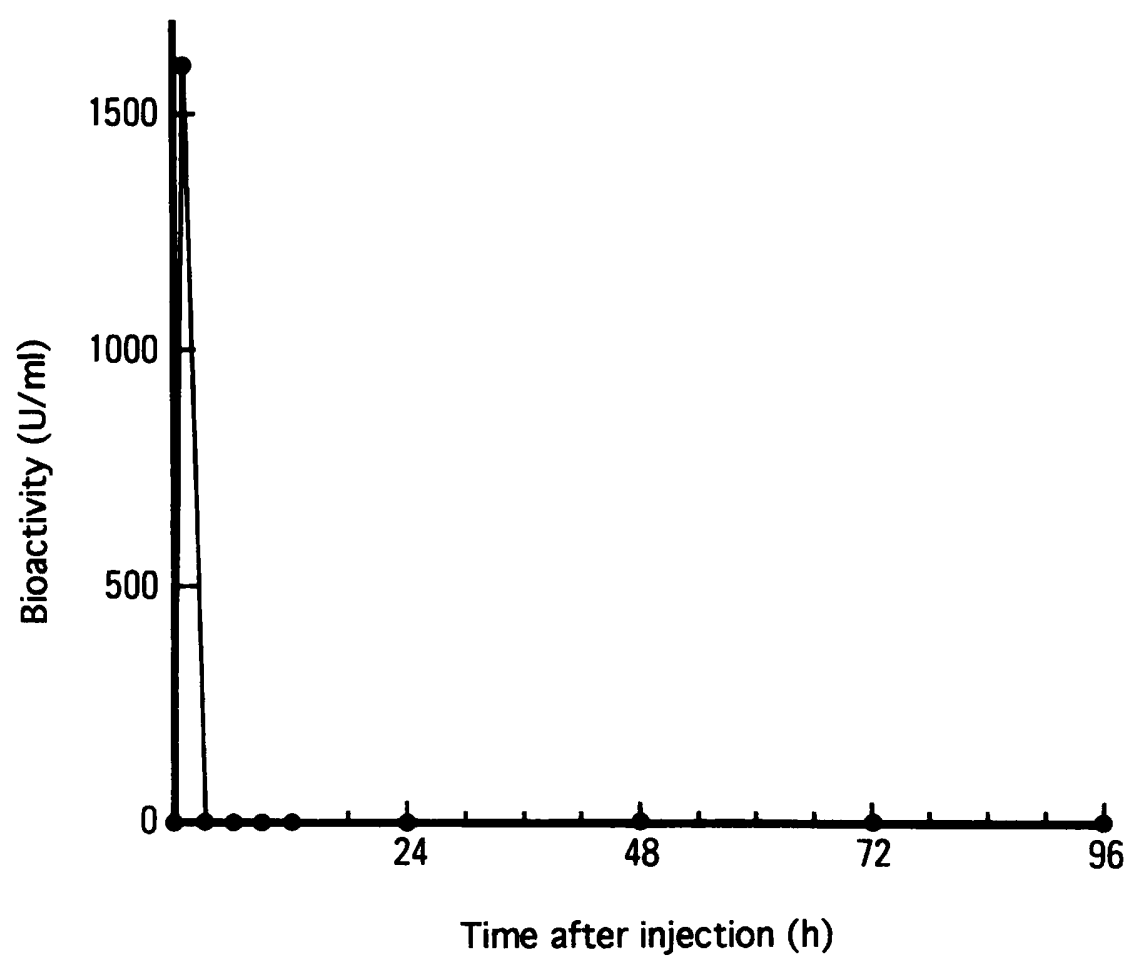

Fig. 3. Serum levels of bioactive TNF after injection of heat-killed $S$. typhimurium ( $50 \mu \mathrm{g} \mathrm{dry} \mathrm{wt/mouse).} \mathrm{Each} \mathrm{point} \mathrm{represents} \mathrm{the} \mathrm{mean} \mathrm{of}$ four readings from two groups of mice. Samples were assayed for TNF bioactivity by a cytotoxicity test with L-929 cells. U, units. 


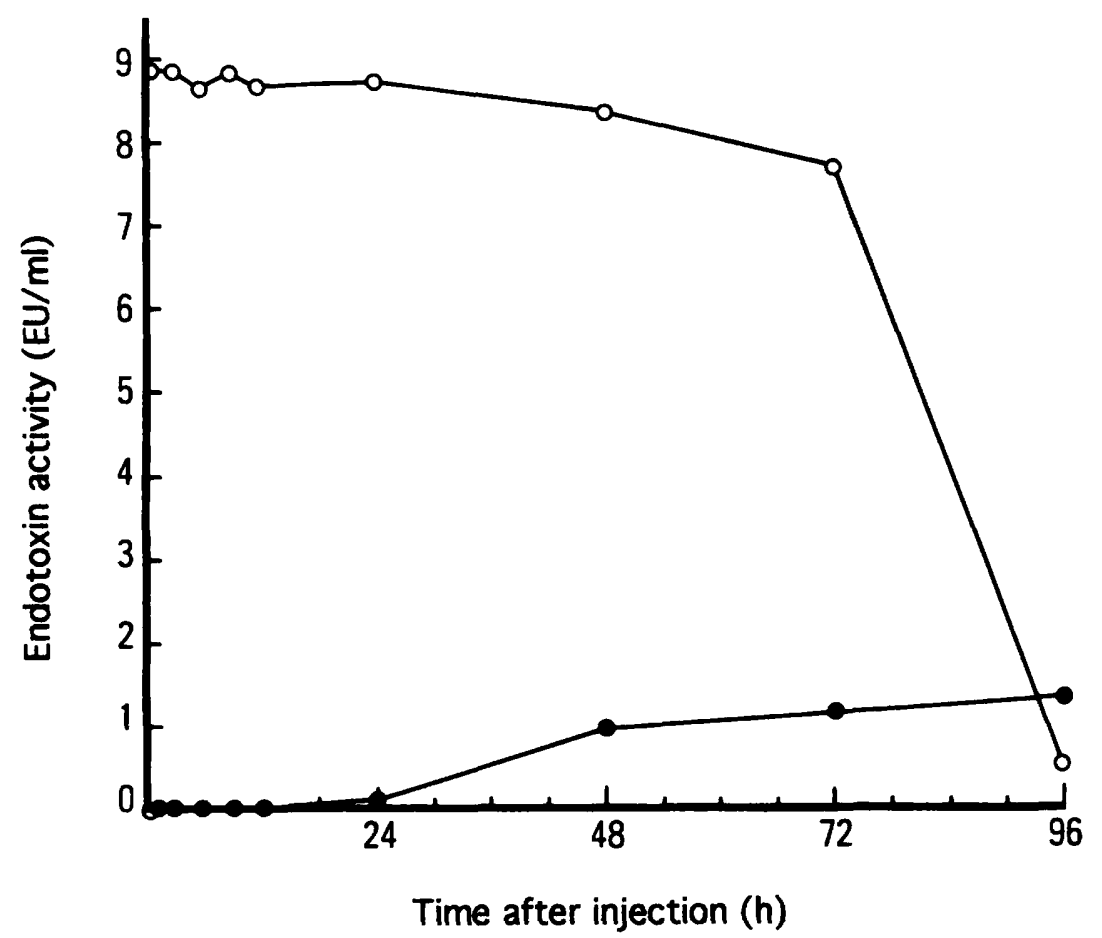

Fig. 4. Serum levels of endotoxin during $S$. typhimurium infection $(10 \mathrm{cfu} / \mathrm{mouse})(--)$ or after injection of heat-killed bacteria ( $50 \mu \mathrm{g}$ dry $\mathrm{wt} /$ mouse) (-O-). Each point represents the mean of four readings from two groups of mice. Endotoxin activity was measured by Limulus amoebocyte lysate assay. EU, endotoxin units.

\section{Discussion}

With the recognition of the important role played by inflammatory mediators in the pathogenesis of sepsis, there has been an increasing interest in studying the pathophysiological consequences of sepsis so that its proper management may be achieved. ${ }^{7}$ Animal models of sepsis could provide valuable information for the development of new therapeutic strategies in terms of their safety, efficacy and pharmacokinetics.

In Ity mice infected with $S$. typhimurium, production of IFN $-\gamma$, a cytokine known to play an important role in host defence against several intracellular pathogens, had peaked on day 3 but had fallen by the fourth day post-infection. Freudenberg et al. ${ }^{2}$ found similar patterns of IFN- $\gamma$ production in congenic mouse strains differing in their LPS responsiveness. Both strains, LPS ${ }^{\mathrm{n}}\left(\mathrm{C} 3 \mathrm{H} / \mathrm{HeN}\right.$; C57BL/10ScSn) and LPS $^{\mathrm{d}}$ $(\mathrm{C} 3 \mathrm{H} / \mathrm{HeJ})$, exhibited transient levels of IFN- $\gamma$ with the peak appearing on day 3 and showing a fall by day 4. Ramarathinam et $a l^{8}$ observed that spleen cells from Ity ${ }^{r}$ mice produced significantly higher levels of IFN- $\gamma$ than spleen cells from Ity ${ }^{\mathrm{s}}$ mice. Their study indicated that the modulation of IFN- $\gamma$ by Ity(r) gene(s) probably plays a role in controlling resistance to Salmonella strains. The role of IFN- $\gamma$ in providing acquired resistance to $S$. typhimurium has also been seen in naturally resistant CBA mice. ${ }^{9}$ In the present study, the drop in the IFN- $\gamma$ levels after day 3 in the Ity ${ }^{\mathrm{s}}$ C57/BL6J mice might have contributed to the mortality that occurred from day 4 onwards.

The role of TNF- $\alpha$ in $S$. typhimurium infection is unclear. Peel et al. ${ }^{3}$ failed to demonstrate circulating levels of TNF- $\alpha$ in calves with $S$. typhimurium septicaemia. However, in naturally resistant CBA mice, antibodies to TNF- $\alpha$ induced proliferation of bacteria in the spleen and subsequent death, indicating that endogenous TNF- $\alpha$ production was necessary for survival. ${ }^{9}$ Exogenous TNF- $\alpha$ has also been shown to be associated with increased resistance to $S$. typhimurium infection. ${ }^{10}$ In the present study, TNF- $\alpha$ levels increased from day 1 onwards, as demonstrated by ELISA. The specificity of the cytokine assay was confirmed by neutralisation with mouse MAbs to TNF- $\alpha$. Surprisingly, the highly immunoreactive TNF- $\alpha$ failed to demonstrate TNF bioactivity in the L-929 cell culture assay. However, sera from mice given heat-killed $S$. typhimurium and handled in the same manner had bioactivity. Kumazawa et al. ${ }^{4}$ also failed to detect TNF bioactivity during infection with $S$. typhimurium in congenic mouse strains differing in their LPS responsiveness. The possible explanations for this important observation could be: (i) although significant TNF levels are produced as a result of $S$. typhimurium infection, they are bound to the circulating TNF receptors shed during the course of infection; ${ }^{11}$ (ii) recently, Luo et al. ${ }^{12}$ showed that gram-negative bacteria, including $S$. typhimurium, have receptors for TNF- $\alpha$ which are heat-labile and, as a consequence of binding of TNF- $\alpha$, their virulence properties may be altered. Therefore, it is possible that bioactivity of any TNF- $\alpha$ produced during infection may be neutralised by binding to the bacterial surface receptors. This hypothesis is further supported by the fact that significant levels of TNF bioactivity were observed after administration of heat-killed bacteria. 
Heat killing is known to destroy TNF receptors on the bacterial surface, thus keeping the bioactivity of TNF intact.

IL-1 has been found to be present in lethal clinical sepsis and to act synergically with TNF- $\alpha$ to induce lethality in animal models. ${ }^{13}$ Low levels of IL-1 were observed in the present study because only IL- $1 \alpha$ was measured and not IL- $1 \beta$. High levels of IL- $1 \beta$ have been observed during sepsis and endotoxaemia. ${ }^{14}$ The level of IL-6, another inflammatory and readily inducible cytokine, showed a good correlation with the outcome of the infection. There is not much information available regarding the role of IL-6 in $S$. typhimurium infection. In one study, IL-6 was found to enhance bactericidal activity and demonstrated a co-operative effect with recombinant human TNF- $\alpha$ during $S$. typhimurium infection in $\mathrm{C} 3 \mathrm{H} / \mathrm{HeJ}$ mice. ${ }^{15}$

In gram-negative bacteria, LPS has been shown to be the main factor inducing many of the pathophysiological changes associated with systemic infection..$^{16}$ After injection of $S$. typhimurium LPS or heat-killed bacteria, all of the cytokines were induced but their time of appearance, level and duration of

\section{References}

1. Plant J, Glynn AA. Locating Salmonella resistance gene on mouse chromosome 1. Clin Exp Immunol 1979; 37: 1-6.

2. Freudenberg MA, Kumazawa Y, Meding S, Langhorne J, Galanos C. Gamma interferon production in endotoxinresponder and -nonresponder mice during infection. Infect Immun 1991; 59: 3484-3491.

3. Peel JE, Voirol M-J, Kolly C, Gobet D, Martinod S. Induction of circulating tumor necrosis factor cannot be demonstrated during septicemic salmonellosis in calves. Infect Immun 1990; 58: 439-442.

4. Kumazawa Y, Freudenberg MA, Hausmann C, Meding-Slade $\mathrm{S}$, Langhorne $\mathrm{J}$, Galanos C. Formation of interferongamma and tumor necrosis factor in mice during Salmonella typhimurium infection. Pathobiology 1991; 59: 194-196.

5. Matsuura M, Galanos C. Induction of hypersensitivity to endotoxin and tumor necrosis factor by sublethal infection with Salmonella typhimurium. Infect Immun 1990; 58: 935-937.

6. Fisch H, Gifford GE. A photometric and plaque assay for macrophage mediated tumor cell cytotoxicity. J Immunol Methods 1983; 57: 311-325.

7. Cross AS, Opal SM, Sadoff JC, Gemski P. Choice of bacteria in animal models of sepsis. Infect Immun 1993; 61: 2741-2747.

8. Ramarathinam L, Niesel DW, Klimpel GR. Ity influences the production of IFN-gamma by murine splenocytes stimulated in vitro with Salmonella typhimurium. I Immunol 1993; 150: 3965-3972. production varied greatly from that seen during sepsis. These distinct kinetic responses during intoxication were probably due to the clearance and detoxification of the endotoxin as evidenced by their decreasing levels with time in the serum. On the other hand, during sepsis there were increasing levels of endotoxin. If a conservative estimate of endotoxin is taken as being $1 \%$ of the dry weight of the bacterial cell ${ }^{7}$ then, in the present study, heat-killed bacteria $(50 \mu \mathrm{g} /$ mouse $)$ induced cytokines more strongly than LPS $(1.2 \mu \mathrm{g} /$ mouse or $>2 \%$ of the dry weight). This suggests that bacterial components other than LPS might play a role in cytokine induction.

Further studies will be required to determine the exact cause of loss of TNF bioactivity during $S$. typhimurium infection, including the possibility of TNF- $\alpha$ binding with the TNF receptors on the bacteria, and to identify non-LPS components of heatkilled bacteria responsible for induction of cytokines. This should prove useful in gaining a better understanding of the pathogenesis of gram-negative infections and their management.

9. Nauciel C, Espinasse-Mase F. Role of gamma interferon and tumor necrosis factor alpha in resistance to Salmonella typhimurium infection. Infect Immun 1992; 60: 450-454.

10. Nakano $Y$, Onozuka K, Terada $Y$, Shinomiya $H$, Nakano $M$. Protective effect of recombinant tumor necrosis factoralpha in murine salmonellosis. J Immunol 1990; 144: 1935-1941.

11. Flad HD, Loppnow H, Rietschel ET, Ulmer AJ. Agonists and antagonists for lipopolysaccharide-induced cytokines. Immunobiology 1993; 187: 303-316.

12. Luo G, Niesel DW, Shaban RA, Grimm EA, Klimpel GR. Tumor necrosis factor alpha binding to bacteria: evidence for a high-affinity receptor and alteration of bacterial virulence properties. Infect Immun 1993; 61 : 830-835.

13. Cross AS, Sadoff JC, Kelly N, Bernton E, Gemski P. Pretreatment with recombinant murine tumor necrosis factor alpha/cachectin and murine interleukin 1 alpha protects mice from lethal bacterial infection. $J$ Exp Med 1989; 169: 2021-2027.

14. Fong Y, Tracey KJ, Moldawar LL et al. Antibodies to cachectin/tumor necrosis factor reduce interleukin-1 beta and interleukin-6 appearance during lethal bacteremia. $J$ Exp Med 1989; 170: 1627-1633.

15. Nakano $\mathrm{M}$, Onozuka K, Yamasu $\mathrm{H}$, Zhong WF, Nakano $\mathrm{Y}$. Protective effects of cytokines in murine Salmonella. Adv Exp Med Biol 1992; 319: 89-95.

16. Weinbaum $\mathrm{G}$ (ed). Bacterial endotoxins. Microbial toxins, vol 4. New York, Academic Press Inc. 1971. 